УДК 342.7:004

DOI https://doi.org/10.30839/2072-7941.2018.155551

\title{
RIGHTS AND FREEDOMS IN INFORMATION AND COMMUNICATION ACTIVITIES OF A MODERN HUMAN
}

\author{
(C) SOSNIN, O. V. \\ Academician Member of the Ukrainian Academy of Political Science (Kyiv, \\ Ukraine) \\ E-mail: alvas.sosnin@gmail.com, ORCID: 0000-0003-4188-0887
}

\begin{abstract}
The urgency of studying the problems of rights and freedoms in the information and communication activities of modern humans is determined by the fact that they exist due to the spread of all new knowledge through the growing functionality of digital information and communication technologies and information processing systems. It begins to rethink the role and significance of the country's information resource. At the same time, the very concept of "information" from the category, which for centuries characterized the system of knowledge, is transforming. The purpose of the study is the conceptualization of rights and freedoms in the information and communication activities of a modern person, which is conditioned by the dissemination of new knowledge through the use of functional capabilities of digital information and communication technologies and information processing systems. Tasks of the research: analysis of technological, ideological and legal problems of the global information and communication space; definition of the conceptualcategorical apparatus of the research - "information", "knowledge", "information security", "jurisdiction of states in the conditions of globalization", "monopolization of legal force" and their influence on the development of information and communication activities of society; formation of the directions of increase of the state information and communication activity of Ukraine for realization of constitutional rights of citizens; consider information law as a science, which allows a new way to consider communication processes that have infocommunication technological horizontals and based on the understanding of the resource of knowledge. The analysis of the latest research and publications that initiated the solution of this problem: the use of articles by O. Dzhoban, O. Sosnin "Information security: new dimensions of threats associated with the intensification of international activities in the field of information and communication"; O. Dovhan "Information resources: national and state, content, concept"; Y.Mastyanitsya, O. Sosnin, L.Shymansky "Information Resources of Ukraine: Problems of Public Administration; M. Ozhevan "National Competitive Exploration in a Globalized World: New Challenges and Threats Against the Background of the" Snowden Case ". The methodology of the research is systematic, structural, structural and functional methods, which allowed to structure the problems and to identify functional relationships between them. Scientific novelty - in the formulation of the very problem rights and freedoms in the information and communication activities of the modern person. Results of the research: the issue of training specialists for the legislative definition of the problems of information and communication, analytical, informational and advocacy and management work in the information sphere; The main information and communication threats to the safety of innovation processes in Ukraine were identified. The conclusion is to create conditions for addressing the security problems of information and communication activities in the implementation of the latest ICT.
\end{abstract}

Rights and freedoms in information and communication activities of a modern human 
Key words: information, information and communication technologies, information and communication activity, information and communication space, human rights and freedoms, information and communication security threats

Problem solving in general and its connection with important scientific or practical tasks

The success of the introduction of scientific and technological progress in the 20th century not only changed the world, but also made Ukraine widespread in the world. On the eve of the reforms of the 1990s we were in the top ten economies of the world, and, incredibly unfortunate, with independence becoming increasingly degraded, they became the leader of begging in the European countries.

It would seem that the direct involvement of the scientific and technical community of Soviet Ukraine in the appearance of personal computers and the latest information and communication technologies (ICTs) provided us with many preferences. Famous achievements of Ukrainian scientists, V.M. Glushkov as a pioneer of the computer era, pushed Ukraine into an innovative economy. Many prominent cyberneticists, mathematicians and engineers of Ukraine were the initiators and organizers of the creation and implementation of comprehensive research programs of development of Ukraine, and it happened so that the emergence of personal computers and the latest ICTs that united humanity with innovation activities, rejected Ukraine the edges of world development. We could not only timely and adequately respond to the emergence of new trends in the organization of socio- political activities, in particular in the legal field, but also did not see the crisis phenomena in the technological development of society in the new conditions of the formation of network information and communication relations and processes work with the content of information [1].

In a situation where, by all countries, the question of creating a new integral theory of law, which combines philosophical, sociological and theoretical and dogmatic knowledge about the right of citizens to information, is left behind, we remain pasty. The significance of the problems of self-development of law and its dependence on the social (and information-communication) environment raises itself by itself and we talk about it a little. In most cases, this topic is discussed in the light of the study of law as a theory in the context of communication development and the functioning of law in the social and political environment in which it exists and in which it exists.

Breaking up the accumulated problems, Ukraine, of course, has to go on unprecedented reforms in the development of its information and communication systems. We talk about this a lot during all years of independence, however, corruption and the formal imitation of the processes of useful activity invented by the bureaucrats, have gained the scale of this disaster and seem to 
prevent society from overcoming it. The existing system of state control overwhelmingly devalues the most interesting and intelligent ideas of the creative thinkers of Ukraine, transforms them into something completely opposite to the intentions. Perhaps it should be recognized that, as a result, we are failing all the models of innovative development of society. The term "innovation" became our only slogan or the most popular assessment of the state and prospects of the development of society, and not the basic principle of the contemporary worldview for the development of socio-political and economic projects to determine the place of people in the world, the motives and purpose of its activity [9]

The analysis of recent researches and publications, which initiated the solution of this problem and based on the author, the allocation of previously unsolved parts of the general problem, which is devoted to the article.

In the article, the author focuses on the work of Dzobany, O. Sosnin "Information security: new dimensions of threats associated with the intensification of international activities in the field of information and communication"; O. Dovhany "Information resources: national and state, content, concept"; Y.Mastyanitsya, O. Sosnin, L.Shymansky "Information Resources of Ukraine: Problems of Public Administration; M. Ozhevan "National Competitive Exploration in a Globalized World: New Challenges and Threats Against the Background of the" Snowden Case ". Today, the creation of a balanced information and communication infrastructure of the state, capable of ensuring the formation, dissemination and effective use and protection of resources, largely depends on a clear legislative definition of the system of views on the purpose, directions and main tasks of the government's implementation of the information and communication function. The purpose of the study is the conceptualization of rights and freedoms in the information and communication activities of a modern person, which is conditioned by the dissemination of new knowledge through the use of functional capabilities of digital information and communication technologies and information processing systems [13].

Formation of the purposes of the article:

- analysis of technological, ideological and legal problems of the global information and communication space;

- to provide definition of information, knowledge, "information security", "jurisdiction of states in the conditions of globalization", "monopolization of legal force and their influence on the development of information and communication activities of society;

- to raise the issue of training specialists for the legislative definition of the problems of information-communication, analytical, informational and advocacy and management work in the information sphere;

- to form the directions of increasing the state information and communication activity of Ukraine for 
realization of constitutional rights of citizens;

- to consider information law as a science, which allows a new way to consider communication processes that have infocommunication technological horizontals and based on the understanding of the resource of knowledge;

- to identify the main information and communication threats to the safety of innovation processes in Ukraine,

Presentation of the main research material with the justification of the received scientific results

The need to resolve the above issues is due to the fact that:

- in today's conditions possibilities for realization of the constitutional rights of citizens to information and freedom of information activity considerably expanded; the needs of the potentially active part of society in the informational interaction have increased considerably both in the country as a whole and in the external world;

- intensive development of global information infrastructure, the necessity of Ukraine's integration into the world information community on equal terms reinforced the dependence of the effective functioning of society and state on the state of development of the information sphere, first of all, the system of state management of national information resources;

$$
\text { information resources, }
$$

information infrastructure in modern conditions become the scene of the international struggle for world leadership, for achieving certain strategic and tactical political goals.
And, what needs to be emphasized especially: the possession of information, proper information provision of state administration bodies, is the basis for a successful fight against modern terrorism.

The main geopolitical issue that faces the state at the beginning of the third millennium is the ability of the country to realize comparative competitive advantages in the coordinates of the global information and communication space in order not to be deprived of real independence and national sovereignty and attributed to the periphery of world development.

Formation of the global information and communication space on a planetary scale in all socially significant spheres of life of societies, causes a lot of technological, ideological and legal problems, since the development of information and telecommunication systems creates as enormous opportunities for the transition of countries to new realities of technological development of the economy, and to it decline All this raises the requirements for the quality of life of people, stimulates them to qualitative education, the development of intellectual and creative abilities, require transformation and even the restructuring of the whole system of scientific and technical and scientific and educational activities. Changes also require reformation of the political and legal basis for the development of the state, and for this there are not enough laws and normative legal acts necessary for the 
computer age on the rights of citizens to use information created by them

If we proceed from the definition of information as information about individuals, objects, facts, events, phenomena and processes, regardless of the form of their presentation, in order to proceed to a more specific perception of information, it is necessary to use an integrated form of it, such as "knowledge". Knowledge is known to be the result of human education and intellectual work. Hence the legal consequence knowledge belongs to the person who creates it, and information - it is only a fraction of knowledge reproduced on the material carriers. Intellectual activity of a person in a society, in the narrow sense, is the work with the carriers of knowledge and information for solving local and global problems. These categories are inextricably linked to one another, and therefore for the effective development of an innovative economy, they must be balanced and meet the requirements of strictly perfect intellectual property and property legislation [6].

Knowledge accumulated by people in the process of education and work, stored for centuries, transmitted as information in various forms and with different method, so the protection of information and knowledge carriers always accompanied the processes of intellectual activity. Hence the tradition of our scientific activity was to conceal publications of defense of dissertations, which diverts the idea of innovation development from the country. Today, the complexity is added to the fact that, along with traditional forms of preservation and transfer of knowledge (book, manuscript, painting, etc.), increasingly spread the digital form of electronic submission of information. In this form, information is increasingly stored in systems of library, archival, business, service, educational activities, structured according to sources and purpose of use. All this creates the necessity of new legislation for the sake of structural perception and the use of different sources of origin, form, accessory knowledge and the purpose of their application as information. The problem requires a deeper study of the sphere of virtual information circulation, its impact on knowledge and public consciousness, on the understanding of the right to information of citizens.

Within the framework of the communicative aspect of law, attention is focused on the issues of the legal language, that is, the language of the legislator, the interpreter, the expert, the user of legal information; the analysis of the language becomes primarily a historical and psycho-cultural problem. The problem of linguistic assessment of the state of terms and concepts, legal definitions is still in the initial stage of development.

Such concepts as "information security", "jurisdiction of states in the conditions of globalization", "monopolization of legal force", etc., often acquire a purely subjective interpretation. Needless to say, what is important for maintaining the rule of law in the state and in the interstate relations is the same understanding of 
tolerance, respect for the person and image of the state, ensuring legal protection of the religious, ethnic culture of the multinational society of the planet.

Globalization, causing everywhere the chaos and crisis of worked out seemingly democratic principles of work with information, "covers" us many problems regarding the intellectual activity of information and communication interaction of knowledge carriers. It was this that we had to realize in a timely manner, taking government policy decisions, to know that ideologues and leaders of the ideas of globalization saw it as a multilevel, equipped with a technocratic rationality system, the upper layer of which is a compact and interconnected information and communication network of metropolitan areas, transport, financial and scientific and educational centers. A great deal of attention was paid to the information and communication nodes that were able to accumulate, store and distribute information and material resources, focusing on all the problems of political and economic realities.

Today's global information and communication space, which is still being actively formed, is not yet subject to the jurisdiction of any state, while the neutrality and availability of knowledge when using modern ICT creates more and more new situations where information sources are used for different and different purposes, sometimes frankly threatening for the modern existence of mankind. As a result, there are many questions about the distribution of the Internet, the operation of which is not defined and not systematized, even for many widely used legal terms. And in such conditions, all the leading countries of the world openly and pragmatically, even aggressively, violating the customary norms of security behavior, lead us to systemic destructive work against us, while protecting our interests in the information and communication sphere [1].

Today, they are considering our objects of information and communication infrastructure, in particular educational ones, as their own. Disclosed recently, facts about the sources of information through the use of technical means of intelligence indicate that the role of the latter is constantly growing and remains an integral part of the system of international relations, i.e., in diplomacy, systems of business and public administration [5]. To counteract such processes, we are disastrously lacking in specialists for the legislative definition of the problems of information and communication, analytical, informational and advocacy and management work in the information sphere. In the conditions of the domination of digital technologies, the problem is objectively deepening and can not be solved by the rhetoric of political leaders, political scientists, sociologists and other specialists in the humanities.

The situation makes for a new and more meticulous look at all the issues of information and communication activities, especially as regards the creation, storage and efficient use of information resources. Analysts, as 
science and the type of work, are the most critical for us. In the cycles of managing any processes, it requires most active mental high-professional work, and therefore the mastery in the education system of knowledge about technology of strategic analysis using high-quality information, including the work of automated network information management complexes and systems, becomes extremely important task for national science and education and public administration.

In the context of solving the problems of building a democratic and protected from distortion of the network information and communication environment in Ukraine, when a full-scale information and military aggression is launched against us, it becomes of great importance - the level of national security problems. It is about the formation in society of a new outlook on all information and communication processes [2].

A challenge to the computer age has become for us and the mastering of processing technologies for large databases (the so-called BigData), the creation of a national regulatory framework for them, etc. BigData can still be interpreted quite widely; however, a simple base of subscribers of telephone networks (even with names and passport data) today should not be attributed to them. They are needed at higher levels of management of socio-political and economic processes. For example, to bind citizens to the movement of mobile devices, their taste and health, and the resolution of problems associated with international terrorism [3].

The problem stimulates the aspiration of many structures and organizations, in particular law enforcement, to expand the concept of "personal data", which has already been partially defined by law, however, so that personal data is considered not only as a surname, name, patronymic, but also a certain set of behavioral factors, on the basis of which one could understand more about a person, as here: where does the purchase of goods, which sites, etc., the question should be more analyzed on the agenda.

Information culture, characterized by culture, from the point of view of information that is accumulated, processed and transmitted within its framework, is considered as a set of norms, rules and stereotypes of behavior associated with information exchange in society. It involves not only a high degree of human competence in the use of information tools, but also the presence of its spiritual and moral personality traits in the context of the recognized human values of the civilized world. S. Grof notes that "Our business ethics, our policy, even our individual lifestyle, are all symptoms of a deeper problem. All our civilization is not viable, and the reason for this is the non-viability of our value system, our very consciousness, which determines our attitude to the world "[4].

State information

and communication activities should create all conditions for the realization of the constitutional rights of citizens of their state freely to receive and use

Rights and freedoms in information and communication activities of a modern human 
information not only in the media, but also in solving issues related to scientific, educational and economic activity. For the formation of the national information and communication space and its inclusion in the global, the formation of a democratically oriented consciousness of citizens and the provision of information sovereignty requires enormous efforts and will of society. After all, the phenomenon of "right" in its philosophical and genetic aspects exists as a virtual state of justice of society, there is a representation of a truly fair (myth) in it, to which the efforts of society are directed, depending on the degree of self-organization in different historical periods and which is realized through freedom of dominant economic, political, etc. power. The analysis shows that the concept of "right" in its ontological aspect in the period XXXXI centuries is realized in normatively-organized systems that emanate from authoritarian or democratic authorities in declaring the guarantees of equality and human rights and citizen (all subjects of civil society), observance of such principles of legal regulation as rule of law, presumption of innocence of the suspect and protection of the rights of the victim, sovereignty of the state power.

Law (legislation) - the main form of legitimate establishment of the legal foundations of society, the rights and responsibilities of actors, their responsibility. How complex is the path from jus to lex, it can be judged from the modern theory to the concept of "rule of law". A concrete example is the implementation of the principle of formal equality of all citizens concerning the law [5].

The law is always regarded as a virtual representation of the fair, expected, possible establishment of the order of interaction between actors of the social system of society, however, because of the legislator's failure to create an ideal model of "rule of law", such a concept in society cannot be fully realized and from this point of view cannot be considered in the form of an ideal theory.

In the conditions of the formation of the principles of innovation economy, the indicated sphere of state activity requires a deep study and consistent reformation and systematization of the law in order to more clearly define the competences of state bodies and update the requirements regarding personal responsibility of citizens in matters of information and innovation activities. In its realm, technology is being developed in the post-industrial world, "hybrid wars" and "information wars", etc., which create new conditions for the management of society [6].

Information law as a science in the conditions of global informatization allows a new way to consider communication processes, which have not only infocommunication technological horizontals, but also based on understanding the depths of the historically achievable level of knowledge resource. It allows us to trace the virtual (cognitive) basis of the connections of the past, the present and the future in the paradigms of development. In this 
connection we turn to the problem of communication in the field of the use of knowledge of such phenomena as "right" and "law". The attention of lawyers to the problems of transformation of the legal system in the conditions of global informatization and globalization of planetary economic, social, political relations became noticeable already within the XX century. In the conditions of globalization and informatization, a peculiar renaissance of philosophy and the theory of law began, an interest in the methodology of legal science and practice has increased. In the new sense, there are such concepts as "jus", "lex", "rule of law", "human rights", "jurisdiction", "sovereignty", etc.

Philosophical, social, sociopsychological aspects of research require a more profound understanding of problems. These are the basics for understanding the concepts of law as "justice", "right", "freedom", "freedom of speech", "freedom of will", "honor", "dignity", "power", "secret" in the world of information, , it is not enough to treat politically only. Even more profound analysis is required by the notion of "legal consciousness", "Orthodoxy", "lawfulness", "law enforcement". In the context of the transition to globalization, as a new stage of development, attention is needed to such tools of knowledge as logic, purpose, content, politics, and art [5].

At the present stage of development of the global community with global integration processes in the field of economy, politics, science,

explosive interest in the innovative use of new knowledge adapted for use with the help of modern information and communication technologies. They are more closely associated with the growing coverage of scientific centers by network technologies and the ideas of innovation development. In the latest concepts and strategies for the development of "smart" or smart societies, "smart governments", "smart education", "smart cities" in different countries of the world, and all this is connected with the formation not only of the "knowledge economy", but with more advanced regulatory and legal bases of the organization of socio-political life.

Smart society is a new quality of society, in which the whole set of processes of gathering and processing knowledge and information with the use of intelligent hardware services. The transition to its technology leads to qualitative changes in the entire system of interaction of subjects, which allows you to get new effects social, economic and other benefits. It is believed that this is the future after the information stage of the development of society, since Smart is the property of an object that characterizes the integration of elements that have not been previously united, for example: Smart-TV, Smart-Home, Smart-Phone and Smart-technology. In general it will lead to an increase in labor mobility for science, education, industry, civil service and many other areas of employment. The main thing is that at the heart of the Smart-society is the development of a "knowledge society", digital technology, digital Rights and freedoms in information and communication activities of a modern human 
society, all that is formed by the "intelligent" organization of information and communication life, state and business, is based on "intelligent" infrastructure and consciousness of "intelligent" "Citizens who play a central role in creating smart-culture, changing the paradigms of society development from production to science and education [6].

For this stage of development of society and economy is characterized by:

- increase of the role of information, knowledge and information technologies in the life of society;

- an increase in the number of people engaged in information technology, communications and the production of information products and services, growth in their share in gross domestic product;

- growth of information society using telephony, radio, television, Internet, as well as traditional and electronic media;

- creation of a global information space, which provides: a) effective information interaction of people; $b$ ) their access to world information resources; c) satisfying their needs in information products and services;

- development of e-democracy, information economy, e-state and government, digital markets, electronic social networks.

The nature, the essence and meaning of the information world are of more interest to society, and information, as a pervading power, acquires new properties with network use. Combining human intellect and artificial intelligence systems, it becomes an information resource for the development of man, society and state, the most important factor in transforming the world order and a new sphere of life for millions of people. Of course, every epoch creates unique techniques and means of rational use of it, and attempts to copy other achievements in the development of an innovative economy, on the one hand, the waste of time on the one hand, on the other, to develop without borrowing and use of someone else's experience for the sake of positive / progressive development is impossible [7].

Right as a phenomenon incorporates the state of society and the idea of establishing general rules of relations between individuals, their associations, with the degree of historical development gives a very important role in the formation of the legal system. The legal system can be considered together and the interaction of many functional and institutional subsystems. These are two aspects of revealing the meaning and forms of the realization of law as phenomena in different periods of development of society under the influence of factors, both external for the system of law, and intra-system, and here opens a huge field for the implementation of various concepts, theories, policies of the development of innovation systems [8].

Of course, Ukraine is facing a lot of dangerous, global levels of challenges today - politically dependent, economically ruined, ideologically devastated. The situation is complicated by the fact that the 
world is constantly transforming, compressing and expanding under the influence of technological inevitable changes related to the development of scientific and technological progress, information and processes of management of material and virtual (informational) flows. All this takes place against the background of the emergence and development of new technologies for the production of integrated circuits, computers, computerized communications for all new ICTs. Chains of consequential relationships that are significant for the modern process of transforming the legal system or the evolution of its individual components can be constructed as follows:

- globalization of the system of economic relations in the postindustrial period and its consolidation as a force largely independent of state power;

- the state of the social system and its updated stratification on economic, ideological and geographical grounds; - liberal philosophy of the transformation of state intervention into these processes, as well as preserved traditional bureaucratic systems for managing the affairs of the state and society, which bear the vices of the industrial age of social development.

By mastering the fundamentals of the new technological postinformational arrangement of humanity, we increasingly understand that intellectual activity will require a person to take as a basis of life not just the work of information, but the search for an innovative component in the information resource for the development of business and the country. The main here is, of course, the definition of the goal, the main principles and methods of the state's implementation of information and communication function. It should be aimed at ensuring national interests and the protection of natural rights and legal and the interests of citizens (individuals), organizations (legal entities) and society as a whole due to the effective use of the accumulated information, modern information and communication complexes and professionals of noble professionally work with them. [9]

Without the experience of resisting the influence of ICTs, we are facing the challenges that face us in all spheres of life, and we are determined to quickly determine where our channel will be to Ukraine, in advance of ensuring its security and state independence. There are not so many ways. In general, we can only consider two: technocratic - the establishment of the total power of technology over people in all manifestations of the organization of our lives; technological - when the level of world outlook and spirituality of human society under the influence of knowledge and development of information technology should gradually become such that the internal possibilities of man to open the use of new, yet unknown ways of harmonious coexistence of man with nature through the use of safe for the biosphere of the Earth and society means [10].

The information development paradigm gives us the opportunity to drastically change the situation and 
create conditions that can put signs of a ban on the path to degradation, provide preferences for the introduction of new environmentally sound technologies. From a systemic point of view, the information (management) component is energy weak, but organizationally it causes processes involving significant (energy, human, material, financial, etc.) resources. Functioning of any technical system is provided by the input of information (which defines the purpose) and provides a controlled process of transformation, obtaining information (on the results of activities) on the output - energy or substance with new parameters [11].

Violation of the integrity or distortion of the basis of information has negative consequences for the results of the functioning of any system, and therefore the problem of its protection in the processes of computerization and development of electronic communication is constantly updated everywhere as technologies have been placed under the strict condition of forming rules of use of global information and communication networks, which requires today a special need for a coherent public policy. Information provides all processes of social life, enriches and harmonizes relations in all areas of life. However, due to the uncertainty of many of its parameters, and especially in terms of computer technology, the ability to convey the meaning of the usual definitions of classical jurisprudence does not always succeed, as the conceptualization of our actions requires in overcoming the problems that arise in the processes of Ukraine's integration into a globalized economic and information and communication environment . In particular, in the field of information and communication security, which today becomes a general scientific problem of the development of a modern innovation world. Today, human information and intelligence have become a special resource for the development of the world, which necessitates the creating of a new legislative package for the harmonious development of all scientific and educational, socioeconomic and cultural structures and international relations that meet the technological requirements of the modern epoch [12].

Regarding the main information and communication threats to the security of innovation processes in Ukraine, they, in our opinion, can be precisely defined and even divided into classes: violation of insider confidential information - involves receiving information by users or processes contrary to the established access rules; Violation of the integrity of the information - presupposes complete or partial destruction, distortion, modification, imposition of false information; violation of the availability of information - involves the loss of (partial or full) performance of the system, blocking access to information; loss of controllability of the information processing system - characterizes the violation of procedures for the identification and authenticity of users and processes, granting them authority, monitoring their activities, 
refusing to receive or forward messages. All this leads to the need for careful action in the state's policy on the implementation of information and communication function. The main thing here, of course, is solving the problems of security features of information and communication activities in the implementation of the latest ICT. All of this allows us to fully understand that in the natural process of reflecting the problems of defining human freedoms and their rights to information, it is always necessary to compare two cartographic notions of universal values - "freedom" and "necessity", "freedom" and "responsibility". As experience in the field of information and communication activities of man, society and the state shows, their rational balance for the sake of the safety of existence must always be achieved [13].

Human security guarantees the prospect of a peaceful future of Ukraine as a sovereign and independent, democratic, social and legal state. The state, through the reform of political-legal relations, should urgently define and ensure the formation of national security features as components, subordinated to the goal of preserving peace and territorial integrity of Ukraine. In domestic politics, this trend can be traced, for example, in the substantial expansion of the powers of law enforcement agencies and special services in the fight against offenses in the use of ICT in the protection of intellectual property, as well as in activities related to the dissent of citizens, and in the foreign policy sphere - in diplomatic activity, promotion of ideas (sometimes amateur), for example, in relation to the controlled management of information exchange processes in global networks. Today, information and communication networks and technologies have become a strategic resource for the development of any country, demonstrating a global strategy for the formation of the world market of information resources and services. That is why the conceptual content of informalism, the very practice of the formation of a new information civilization by all researchers today is mostly considered through the informatization of society and the functioning of global information and communication infrastructures. Even under conditions of incomplete understanding of the methods of processing large volumes of information in the process of transforming knowledge into capital, humanity is rapidly upgrading and commercializing a globally informative and communicative environment, increasingly subordinating it to the realization of its needs, not only for the development of globular communication the media, and establishes the foundations of a new information economy of knowledge, seeks new methods for implementing their plans in the political, economic and military spheres.

\section{Conclusions from the study and perspectives of further exploration in this direction}

The global trends of the first period of the twenty-first century allow us to assert that under such 
conditions, further formation of a new type of states, societies, their policies, economics, military affairs and, of course, science and education will take place. On this basis, the formation of a fundamentally new economy (knowledge-based economy) is taking place today, and the basis for the competitiveness of countries is the ability to accumulate and rational utilization of fundamental knowledge - information on the basis of which new breakthrough technologies are created of hightech). Under such conditions, the knowledge and ability of students of technical universities (non-taxed) acquire special value and will increasingly be actively involved in the management of tangible and intangible resources of society, in particular. Ukraine today, in order not to remain on the verge of world scientific and technological upgrading, it is necessary to integrate into the world of innovative technological trends regarding the use of intangible assets of society. Based on this, in the shortest possible time we will be able to switch not only on the innovative way of economic development, but also to select (define) their priorities in scientific and technological development, and, as a result, to create a national innovation system.

\section{REFERENCES}

1. Dzeban, A., Sosnin, A. (2015). Information security: new dimensions of threats, associated with the intensification of international activities in information and communication sphere. Visnyk of the Lviv University. Series International Relations, 37 (3), 35-43.

2. Dovhan, O. D. (2015). Informatsiyni resursy: natsionalni ta derzhavni, zmist, poniattia. Informatsiya i pravo, 3 (15), 85-91.

3. Grof, S., Laslo, E., Rassel, P. (2004). Revolyuciya soznaniya: Transatlanticheskiy dialog. Moscow: Izd. ACT, 20.

4. Mastianytsia, Y. U., Sosnin, O. V., Shymanskyi, L. Ye.; Sosnin, O. V. (Ed.) (2002). Informatsiini resursy Ukrainy: problemy derzhavnoho upravlinnia. Kyiv: NISD, 140.

5. Korsak, K. V., Korsak, Y. K. (2018). The only way to save humanity from total collapse - nootechnologies and noosciences. Humanities Bulletin of Zaporizhzhe State Engineering Academy, 74, 28-38. doi: https://doi.org/10.30839/2072-7941.2018.149632

6. Melnyk, V. V. (2018). Information management as a factor of innovative society development. Humanities Bulletin of Zaporizhzhe State Engineering Academy, 74, 39-47. doi: https://doi.org/10.30839/2072-7941.2018.149651

7. Ozhevan, M. (2013). Natsionalna konkurentna rozvidka u hlobalizovanomu sviti: novi vyklyky i zahrozy na tli «kazusu Snoudena». Stratehichni priorytety, 4 (29), 131-139.

8. Proekt Kontseptsiyi informatsiynoi bezpeky Ukrainy. Available at: http://mip.gov.Ua/done_img/d/30-project_08_06_15.pdf

9. Punchenko, O. P., Voronkova, V. H., Andriukaitiene, R. (2018). Sociodynamics of the globalizing world in its civilization dimension. Humanities Bulletin of Zaporizhzhe State Engineering Academy, 74, 48-60. doi: https://doi.org/10.30839/2072-7941.2018.149652

10. Dzoban, A., Sosnin, A. (2015). Information security: new dimensions threats related information and communication sphere. Humanities Bulletin of Zaporizhzhe State Engineering Academy, 61, 24-34.

11. Sosnin, O. V. (2003). Problemy derzhavnoho upravlinnia systemoiu natsionalnykh informatsiynykh resursiv z naukovoho potentsialu Ukrainy. Kyiv: Instytut derzhavy i prava im. V. M. Koretskoho NAN Ukrainy, 572. 
12. Sosnin, A. (2016). Pro vymir systemy vyshchoi tekhnichnoi osvity v koordynatakh problem natsionalnoi bezpeky. Humanities Bulletin of Zaporizhzhe State Engineering Academy, 66, 123-134. doi: https://doi.org/10.30839/2072-7941.2016.78583

13. Sosnin, O., Voronkova, V., Azhazha, M. (2016). Filosofiya humanistychnoho menedzhmentu (sotsialno-politychni, sotsialno-ekonomichni, sotsialno-antropolohichni vymiry). Zaporizhzhia: Dyke pole, 356.

СОСНІН, О. В. - доктор політичних наук, професор, професор, заслужений діяч науки і техніки України, академік Української академії політичних наук (Київ, Україна)

E-mail: alvas.sosnin@gmail.com, ORCID: 0000-0003-4188-0887

\section{ПРАВА ТА СВОБОДИ В ІНФОРМАЦИЙНО-КОМУНІКАЦІЙНІЙ ДІЯЛЬНОСТІ СУЧАСНОї ЛЮДИНИ}

Анотація. Актуальність дослідження проблем прав та свобод в інформаційнокомунікаційній діяльності сучасної людини визначається тим, що вони обумовлені поширенням все нових знань за допомогою зростаючих функціональних можливостей цифрових інформаційно-комунікаційних технологій і систем обробки інформації. В сучасних умовах починає переосмислюватися роль та значення інформаційного ресурсу країни. При цьому само поняття «інформація» із категорії, яка століттями характеризувала систему знань, трансформується. Мета дослідження концептуалізація прав та свобод в інформаційно-комунікаційній діяльності сучасної людини, що зумовлена поширенням нових знань за допомогою функціональних можливостей цифрових інформаційно-комунікаційних технологій і систем обробки інформації. Завдання дослідження: аналіз технологічних, світоглядних і правових проблем глобального інформаційно-комунікаційного простору; визначення поняттєвокатегоріального апарату дослідження - «інформація», «знання», «інформаційна безпека», «юрисдикція держав в умовах глобалізації», «монополізація правової сили» та їх вплив на розвиток інформаційно-комунікаційної діяльності суспільства; формування напрямів підвищення державної інформаційно-комунікаційної діяльності України для реалізації конституційних прав громадян; розглянути інформаційне право як науку, що дозволяє по-новому розглядати комунікаційні процеси. Аналіз останніх досліджень і публікацій, 3 яких започатковано розв'язання даної проблеми: використання статей О. Дзьобаня, О. Сосніна «Інформаційна безпека: нові виміри загроз, пов'язаних 3 активізацією міжнародної діяльності в інформаційно-комунікаційній сфері»; О. Довганя «Інформаційні ресурси: національні та державні, зміст, поняття»; Й.Мастяниці, О. Сосніна, Л. Шиманського «Інформаційні ресурси України: проблеми державного управління; М. Ожевана «Національна конкурентна розвідка у глобалізованому світі: нові виклики і загрози на тлі «казусу Сноудена. Результати дослідження : поставлено питання підготовки фахівців для законодавчого визначення проблем інформаційно-комунікаційної, аналітичної, інформаційно-пропагандистської та управлінської роботи в інформаційній сфері; виявлено головні інформаційнокомунікаційні загрози безпеки інноваційних процесів в Україні. Висновок сформувати умови для вирішення проблем безпекових характеристик інформаційнокомунікаційної діяльності при впровадженні новітніх IКТ.

Ключові слова: інформація, інформаційно-комунікаційні технології, інформаційно-комунікаційна діяльність, інформаційно-комунікаційний простір, права та свободи людини, інформаційно-комунікаційні загрози безпеки

СОСНИН, А. В. - доктор политических наук, профессор, Заслуженный деятель науки и техники Украины, академик Украинской академии политических наук (Киев, Украина)

E-mail: alvas.sosnin@gmail.com, ORCID: 0000-0003-4188-0887

Rights and freedoms in information and communication activities of a modern human 


\section{ПРАВА И СВОБОДЫ В ИНФОРМАЦИОННО-КОМУНИКАЦИОННОЙ ДЕЯТЕЛЬНОСТИ СОВРЕМЕННОГО ЧЕЛОВЕКА}

Аннотация. Актуальность исследования проблем прав и свобод в информационно коммуникационной деятельности современного человека определяется тем, что они обусловлены распространением все новых при помощи функциональных возможностей цифровых информационно-коммуникационных технологий и систем обработки информации. В современных условиях начинает переосмысливаться роль и значение информационного ресурса. При этом само понятие «информации» из категории, которая столетиями характеризовала систему «знаний», трансформируется. Цель исследования - концептуализация прав и свобод в информационнокоммуникационной деятельности современного человека, которая обусловлена распространением новых знаний при помощи функциональных возможностей цифровых информационно-коммуникационных технологий и систем обработки информации. Задачи исследования: анализ технологических, мировоззренческих и правовых проблем глобального информационно-коммуникационного пространства; определение понятийно-категориального аппарата исследования - «информация», «знание», «информационная безопасность», «юрисдикция государств в условиях глобализации», «монополизация правовой силы» и их влияние на развитие информационно-коммуникационной деятельности общества; формирование направлений повышения государственной информационно-коммуникационной деятельности Украины для реализации конституционных прав граждан; анализ «информационного права» как науки, которая по-новому позволяет рассмотреть коммуникационные процессы. Анализ последних достижений и публикаций, в которых представлено решение данной проблемы: использование стаей А.Дзебаня, А.Соснина «Информационная безопасность: новые измерения угроз, связанных с активизацией международной деятельности в информационно-коммуникационной сфере»; А.Довганя «Информационные ресурсы: национальные и государственные, содержание, понятие»; И. Мастяницы, А.Соснина, Л.Шиманского «Информационные ресурсы Украины: проблемы государственного управления»; Н.Ожевана «Национальная конкурентная разведка в глобализированном мире: новые вызовы и угрозы на основе «каузуса Сноудена», Результаты исследования: поставлен вопрос о подготовке специалистов для законодательного определения проблем информационнокоммуникационной, аналитической, информационно-пропагандистской и управленческой работы в информационной сфере; выявлены главные информационнокоммуникационные угрозы безопасности инновационных процессов в Украине. Вывод - сформировать условия для решения проблем безопасных характеристик информационно-коммуникационной деятельности при внедрении новых ИКТ.

Ключевые слова: информация, информационно-коммуникационные технологии, информационно-коммуникационная деятельность, информационно-коммуникационное пространство, права и свободы человека, информационно-коммуникационные угрозы безопасности

Стаття рекомендована до публікаиії д.філософ.н., проф. В.Г.Воронковою (Запоріжжя, Україна)

Надійшла до редколегї: 02.11.2018 p. Прийнята до друку: 07.11.2018 p. 